\title{
KEKERASAN DALAM PACARAN PADA SISWA SMA DITINJAU DARI KONFORMITAS TEMAN SEBAYA DAN EFEKTIVITAS KOMUNIKASI DALAM KELUARGA
}

\author{
Anna Dian Savitri, S.Psi, M.Si,Psikolog \\ Fitria Linayaningsih, S.Psi., M.Psi., Psikolog \\ L. Rini Sugiarti, S.Psi.,M.Si, Psikolog
}

\begin{abstract}
Abstrak
Penelitian ini bertujuan untuk mengetahui hubungan konformitas teman sebaya dan efektivitas komunikasi orang tua dengan kekerasan dalam pacaran pada remaja. Penelitian dilakukan pada 70 siswi SMAN "X" Semarang yang sudah memiliki pacar. Metode yang digunakan dalam penelitian ini adalah kuantitatif, dengan menggunakan skala sebagai alat ukur. Berdasarkan analisis hasil penelitian diketahui bahwa korelasi konformitas dengan KDP sebesar 0,424. sedangkan korelasi efektivitas dengan KDP sebesar 0,381.selain itu didapatkan data juga bahwa subyek yang mengalami kekerasan verbal sebanyak $13,5 \%$, subyek yang mengalami kekerasan seksual sebanyak 42,7 \%, subyek yang mengalami kekerasan Fisik sebanyak 42,7\%. Berdasarkan penggalian informasi terhadap subyek yang mengalami KDP, ratarata masih banyak yang belum memahami bentuk-bentuk KDP secara verbal, karena mereka cenderung menganggap KDP verbal apabila dimarahi,dibentak, diancam, dan dilarang melakukan ini itu. KDP Seksual yg dialami rata-rata adalah pelecehan seksual dalam bentuk diraba-raba dan dicium paksa oleh pasangannya. KDP Fisik yang dialami rata-rata didorong, ditarik,ditampar oleh pasangannya.
\end{abstract}

Kata Kunci : KDP, Konformitas, Efektivitas Komunikasi

\begin{abstract}
This research aims to understand the relationship conformity their peers and effectiveness of communication parents by force in courtship in adolescents. This research was done on the students of 70 SMAN ' $X$ ' Semarang thar already has a boyfriend. Methods used in this research is quantitative, by the use of the scale as a measuring instrument. Based on the analysis of the results of the study known that the correlation signs of conformity with dating violence 0,424 as much as. While correlation with dating violence the effectiveness of 0,381.In addition it was obtained also that subjects him that experienced verbal violence as many as $13,5 \%$, the subject that experienced sexual violence as many as 42,7\%, the subject that experienced physical violence as many as $42,7 \%$.

Based on the information, the subject is experiencing dating violence average are still not yet perceive shapes dating violence verbally, because they tend to regard dating violence verbal if scolded, snapped,death threats, and forbidden to do this dating violence experienced sexual the average is actually sexually assaulted in the palpable and kissed forced by his spouse dating violence to be driven, on average, drawn, got slapped by her partner
\end{abstract}

Keywords : dating violence, conformity, communication 


\section{PENDAHULUAN}

\section{Latar Belakang}

Fenomena perilaku pacaran di kalangan remaja sudah sangat umum. Hampir sebagian besar remaja yang sekaligus siswa ini telah dan pernah berpacaran, baik remaja kota maupun remaja desa. Hal ini dapat terlihat di salah satu media massa yang membidik anak usia sekolah menengah terkait masalah hubungan antar lawan jenis atau biasa dikenal dengan istilah pacaran. Riset yang dilakukan KPAI di 12 kota di Indonesia tahun 2010, menunjukan bahwa dari 2.800 responden pelajar, $76 \%$ perempuan dan $72 \%$ laki-laki pernah mengaku berpacaran (Andri Haryanto, 2010). Berpacaran dapat memberikan kontribusi positif maupun negatif bagi remaja yang berpacaran. Hasil penelitian yang dilakukan oleh Saadatun Nisa (2008), menunjukan bahwa berpacaran dapat memberikan kontribusi positif bagi remaja yang berpacaran. Hasil positif yang didapatkan oleh remaja yang berpacaran adalah ketika mereka dihadapkan oleh suatu konflik, maka jalan untuk menyelesaikan konflik adalah dengan pengendalian diri di antara mereka. Pengendalian diri tersebut di antaranya yaitu kesabaran dan berpikir positif. Selain itu, masa remaja juga merupakan masa yang rentan untuk terpengaruh hal negatif misalnya melakukan bentuk-bentuk perilaku seksual remaja yang beresiko: gaya pacaran yang tidak sesuai norma, seks pranikah, kehamilan tidak dikehendaki (KTD), aborsi, kekerasan dalam berpacaran (KDP)

KDP tergolong dalam satu bentuk penyimpangan perilaku remaja yang kasusnya biasa terjadi, namun kadang tanpa disadari baik itu oleh korban, atau bahkan pelakunya sendiri.
Banyak rasionalisasi yang dilakukan oleh pelaku maupun korban kekerasan. Hal tersebut dikarenakan ketika insan sedang jatuh cinta, rasa indah selalu seperti hidup di surga. Data kasus kekerasan yang ditangani oleh Jaringan Relawan Independen (JaRI) periode April 2002-Juni 2007, yakni, dari 263 kasus kekerasan yang masuk, ada 92\% korban perempuan (sekitar 242 orang). Dimana sepertiganya merupakan kekerasan dalam pacaran (KDP). Sementara itu, kasus kekerasan dalam pacaran (KDP) dan perkosaan pun menjadi kasus dominan yang ditangani Rifka Annisa Women`s Crisis Center asal Yogyakarta, setelah kekerasan terhadap istri. Selama 14 tahun terakhir, dari 3.627 kasus kekerasan terhadap perempuan yang terungkap, sekitar $26 \%$ di antaranya adalah kekerasan dalam pacaran (KDP) dan perkosaan. Rifka Annisa (2002) mencatat bahwa kekerasan terhadap perempuan yang terjadi antara bulan Januari-Juli 2002 tercatat sebanyak 248 kasus. Dimana 60 kasus merupakan kekerasan pada masa pacaran (KDP) dan perkosaan 30 kasus.

Pengaruh keluarga sangat besar dalam membentuk kepribadian seseorang. Masalah-masalah emosional yang kurang diperhatikan oleh orang tua dapat memicu timbulnya permasalahan bagi individu yang bersangkutan di masa yang akan datang. Pengaruh peer group atau konformitas teman sebaya juga menjadi salah satu penyebab munculnya kecenderungan remaja melakukan KDP. Adanya berbagai kasus mengenai KDP, menjadikan peneliti tertarik untuk mengusulkan penelitian ini dengan harapan akan mengetahui Bagaimanakah $\mathrm{Ke}$ kerasan Dalam Pacaran pada Siswa SMA ditinjau dari Konformitas Teman Sebaya dan Efektivitas Komunikasi Orang Tua? 
Penelitian ini bertujuan untuk mengetahui hubungan kekerasan dalam pacaran pada siswa SMA dengan konformitas teman sebaya dan efektivitas komunikasi orang tua.

Hipotesis penelitian : Ada hubungan negatif antara konformitas positif teman sebaya dan efektivitas komunikasi orang tua dengan kekerasan dalam pacaran. Semakin tinggi konformitas teman sebaya dan efektivitas komunikasi orang tua, maka semakin rendah kekerasan dalam pacaran, begitu pula sebaliknya.

\section{METODE PENELITIAN}

\section{Identifikasi Variabel Penelitian}

Adapun variabel-variabel dalam penelitian ini terdiri atas :

1. Variabel tergantung

Kekerasan Dalam Pacaran

2. Variabel bebas

Konformitas Teman Sebaya dan

Efektivitas Komunikasi

\section{Subyek Penelitian}

Populasi yang akan diambil dalam penelitian ini ada siswi kelas XI SMAN 14 Semarang. Adapun penelitian ini menggunakan purposive sampling, yaitu teknik penentuan sampel sesuai dengan kriteria yang ditentukan oleh peneliti.

\section{Metode Pengumpulan Data}

\section{Alat Pengumpulan Data}

Penelitian ini menggunakan Skala Kekerasan dalam Pacaran, Skala Konformitas Teman Sebaya dan Skala Efektivitas Komunikasi.

\section{Uji Validitas dan Relibilitas Alat Ukur}

\section{a. Validitas Validitas}

Azwar (2009:5) mengemukakan bahwa validitas berasal dari kata validity yang mempunyai arti sejauh mana ketepatan dan kecermatan suatu alat ukur dalam melakukan fungsi ukurnya. Suatu instrumen pengukur dapat dikatakan mempunyai validitas yang tinggi apabila alat tersebut menjalankan fungsi ukurnya yang sesuai dengan maksud dan tujuan diadakannya tes tersebut. Guna menguji validitas, maka digunakan metode analisis aitem. Cara yang digunakan adalah dengan mencari koefisien korelasi antar skor yang diperoleh setiap aitem dengan skor totalnya.

Teknik yang digunakan dalam mencari koefisien korelasi pada penelitian ini adalah teknik korelasi Product Moment dari Pearson Hadi (2009: 264) dan dikorelasikan dengan menggunakan teknik korelasi Part Whole. Pengolahan data dilakukan dengan menggunakan SPSS ( Statistical Packages for Social Science) for windows versi 16.00. Rumus Korelasi Product Moment

$r_{x y}=\frac{N \sum X Y-\left(\sum X\right)\left(\sum Y\right)}{\sqrt{\left\{N \sum X^{2}-\left(\sum X\right)^{2}\right\}\left\{N \sum Y^{2}-\left(\sum Y\right)^{2}\right\}}}$

Keterangan:

$\mathrm{r}_{\mathrm{xy}}: \begin{aligned} & \text { Indeks } \\ & \text { korelasi antara skor aitem } \\ & \text { dengan skor total }\end{aligned}$
$\sum \mathrm{XY}: \begin{aligned} & \text { Jumlah perkalian antara skor } \\ & \text { aitem dengan skor total }\end{aligned}$
$\sum \mathrm{X}: \begin{aligned} & \text { Jumlah skor masing-masing } \\ & \text { aitem }\end{aligned}$
$\sum \mathrm{Y}:$ Jumlah skor total
$\mathrm{N}:$ Jumlah subjek


Rumus Part Whole:

$$
r_{p q}=\frac{\left(r_{x y}\right)\left(S D_{y}\right)-\left(S D_{x}\right)}{\sqrt{\left(S_{y^{2}}+S D_{x^{2}}\right)-2\left(r_{x y}\right)-\left(S D_{x}\right)\left(S D_{y}\right)}}
$$

Keterangan:

rpq : koefisien korelasi aitem dan total setelah dikoreksi

rxy : koefisien korelasi item dan total sebelum dikoreksi

SDx : standar deviasi skor total

Sdy : standar deviasi skor item

\section{b. Reliabilitas}

Sanders, McKormick (1992: 19) mengemukakan bahwa suatu penelitian dianggap reliabel dan dapat dipercaya ketika tidak ada error penelitian. Selain itu menurut Azwar (2008: 6) mengemukakan mengenai reliabilitas alat ukur menentukan sejauhmana hasil pengukuran dengan alat tersebut dapat dipercaya. Teknik yang digunakan untuk menentukan reliabilitas skala dalam penelitian ini adalah teknik analisis varians dari Alpha Cronbach. Pengolahan data dilakukan dengan menggunakan SPSS ( Statistical Packages for Social Science) 16.00.

Rumus Alpha Cronbach.:

$$
\alpha=\frac{\mathrm{K}}{\mathrm{K}-1}\left[1-\frac{\sum \mathrm{S}_{\mathrm{x}}^{2}}{\sum \mathrm{S}_{\mathrm{t}}^{2}}\right]
$$

Keterangan:

$\alpha=$ koefisien reliabilitas alpha

$\mathrm{k} \quad=$ jumlah butir item

$\sum \mathrm{S}_{\mathrm{x}}^{2}=$ varians butir item

$\sum \mathrm{S}_{\mathrm{t}}^{2}=$ varians skor total

\section{Metode Analisis Data}

Analisis data adalah cara yang digunakan dalam mengolah data yang diperoleh sehinga didapat suatu kesimpulan. Metode analisis data bertujuan menyederhanakan data ke dalam bentuk yang lebih mudah dibaca dan diinterpretasikan. Menganalisis data merupakan suatu langkah yang sangat kritis dalam penelitian. Dalam penelitian ini teknik korelasi Product Moment digunakan untuk melihat hubungan antara Kekerasan Dalam Pacaran dengan Konformitas Teman Sebaya dan Efektivitas Komunikasi.

Adapun rumus korelasi Product Moment menurut Sugiyono (2010) sebagai berikut :

$r_{x y}=\frac{N \sum X Y-\left(\sum X\right)\left(\sum Y\right)}{\sqrt{\left\{N \sum X^{2}-\left(\sum X\right)^{2}\right\}\left\{N \sum Y^{2}-\left(\sum Y\right)^{2}\right\}}}$

Keterangan:

$r_{x y} \quad$ : Indeks korelasi/koefisien korelasi antara skor aitem dengan skor total

$\sum X Y$ : Jumlah perkalian antara skor aitem dengan skor total

$\sum X$ : Jumlah skor masing-masing aitem

$\sum \mathrm{Y}:$ Jumlah skor total

$\mathrm{N} \quad$ : Jumlah subjek

\section{HASIL DAN PEMBAHASAN \\ Hasil}

1. Uji Validitas dan Reliabilitas

Pengujian validitas alat ukur dilakukan dengan menggunakan perhitungan program SPSS for Windows Release 17.0

a. Skala Kekerasan Dalam Pacaran

Hasil analisis item skala KDP menunjukkan dari 36 item terdapat 25 item yang valid dan 11 item yang gugur, dengan koefisien corrected correlation berkisar 0,268 - 0,802. Hasil perhitungan 
item secara lengkap dapat dilihat pada lampiran.

\section{b. Skala Konformitas}

Hasil perhitungan item skala konformitas menunjukkan dari 32 item terdapat 13 item yang valid dan 21 item yang gugur. Setelah 21 item yang gugur itu dihilangkan, dilakukan penghitungan putaran kedua, dan terdapat 12 item valid, dan 1 item gugur, setelah item yang gugur dihilangkan kemudian pada putaran ketiga semua item dinyatakan valid dengan koefisien corrected correlation berkisar 0,268 - 0,819. Hasil perhitungan item yang valid dan gugur dapat dilihat pada lampiran.

\section{c. Skala Efektivitas Komunikasi}

Hasil perhitungan item skala efektivitas komunikasi menunjukkan dari 30 item terdapat 22 item yang valid dan 8 item yang gugur dengan koefisien corrected correlation berkisar 0,291 0,914 . Hasil perhitungan item selengkapnya dapat dilihat pada lampiran.

Teknik untuk menguji reliabilitas pada tiga skala dalam penelitian ini menggunakan teknik Alpha Cronbach. Uji reliabilitas dilakukan berdasarkan item-item yang valid. Untuk skala kekerasan dalam pacaran diperoleh hasil koefisien Alpha 0,912, dan untuk skala konformitas diperoleh hasil koefisien Alpha 0,861. Sedangkan untuk skala efektivitas komunikasi menunjukkan koefisien Alpha 0,950. Berdasarkan hasil perhitungan tersebut maka dapat disimpulkan bahwa ketiga skala tersebut reliabel.

\section{Uji Asumsi}

a. Uji Normalitas

Uji normalitas data dimaksudkan untuk mengetahui normal tidaknya distribusi data masing-masing variabel penelitian, yaitu variabel kekerasan dalam pacaran.konformitas, efektivitas komunikasi. Teknik analisis uji normalitas data penelitian menggunakan Uji Kolmogorov-Smirnov dengan menggunakan komputer program SPSS for Window Release 17.0, dapat diketahui bahwa :

1) Variabel kekerasan dalam pacaran berdistribusi tidak normal, dengan nilai $\mathrm{K}-\mathrm{S} \mathrm{Z}=0,001$ : $\mathrm{p}<0,05$.

2) Variabel konformitas berdistribusi normal, dengan nilai $\mathrm{K}-\mathrm{S} \mathrm{Z}=0,200$; $\mathrm{p}>0,05$.

3) Variabel efektivitas komunikasi berdistribusi tidak normal, dengan nilai $\mathrm{K}-\mathrm{S} \mathrm{Z}=0,036$; $\mathrm{p}<0,05$.

b. Uji Linieritas

Hasil uji linieritas dengan menunjukkan bahwa :

1) Variabel konformitas terhadap kekerasan dalam pacaran bersifat linier dengan $\mathrm{F}$ linier $=16,338$ dengan $\mathrm{p}<0,05$

2) Varibel efektivitas komunikasi terhadap kekerasan dalam pacaran bersifat linier dengan $\mathrm{F}$ linier = 18,994 dengan $\mathrm{p}<0,05$

\section{Uji Hipotesis}

Berdasarkan data yang telah diperoleh yang telah memenuhi syarat, maka dilakukan analisis uji hipotesis dengan menggunakan program SPSS for windows release 17.0. Hubungan konformitas dengan kekerasan dalam pacaran sebesar 0,424 dan dan efektivitas komunikasi dengan kekerasan dalam pacaran sebesar $-0,381$, dengan demikian hipotesis penelitian diterima.

\section{Pembahasan}

Penelitian dilakukan pada 70 siswi SMAN "X" Semarang yang sudah memiliki pacar. Diketahui bahwa : 
Korelasi konformitas dengan KDP sebesar 0,424. Sedangkan korelasi efektivitas dengan KDP sebesar 0,381. Dengan demikian hipotesis penelitian diterima. Selain itu didapatkan pula data bahwa subyek yang mengalami kekerasan verbal sebanyak $13,5 \%$, subyek yang mengalami kekerasan seksual sebanyak $42,7 \%$, subyek yang mengalami kekerasan Fisik sebanyak 42,7\%. Berdasarkan penggalian informasi terhadap subyek yang mengalami KDP, rata-rata masih banyak yang belum memahami bentukbentuk KDP secara verbal, karena mereka cenderung menganggap KDP verbal apabila dimarahi, dibentak, diancam, dan dilarang melakukan ini itu. KDP Seksual yg dialami rata-rata adalah pelecehan seksual dalam bentuk dirabaraba dan dicium paksa oleh pasangannya. KDP Fisik yang dialami rata-rata didorong, ditarik, ditampar oleh pasangannya. Konformitas teman sebaya dan komunikasi orangtua memiliki kontribusi terhadap KDP yang dialami oleh remaja.

\section{PENUTUP}

\section{A. Simpulan}

1) Komformitas dengan teman sebaya memberikan kontribusi terhadap munculnya perilaku KDP pada remaja.

2) Remaja yang berkumpul dengan teman yang sering menjadi korban KDP, cenderung menerima perlakuan KDP dari pasangannya dikarenakan tidak mau kehilangan pasangan.

3) Efektivitas komunikasi remaja dengan orangtua memberikan kontribusi karena pada masa remaja ini kelekatan dengan teman sebaya lebih memberikan pengaruh terhadap gaya berpacaran pada remaja.
B. Saran

1) Pihak sekolah lebih mengaktifkan fungsi Kelompok KRR (Kesehatan Reproduksi Remaja) yang ada di sekolah, sehingga para siswa lebih memahami pacaran sehat dan mengenali bentuk-bentuk KDP.

2) Diberikan pelatihan pada siswa-siswi agar lebih aserif dalam menghadapi KDP.

3) Orangtua lebih membuka diri untuk mengajarkan pendidikan seks sejak dini pada anak.

\section{DAFTAR PUSTAKA}

Ayu, dkk. 2009. Hubungan Antara Konformitas Terhadap Teman Sebaya Dengan Intensi Merokok Pada Remaja Perempuan Di SMA Kesatrian 1 Semarang. Jurnal Psycho Idea. Tahun 7, No. 2.

Dariyo, Agoes, "Psikologi Perkembangan Remaja”, Ghalia Indonesia, Jakarta, 2004

Ferlita, Gracia. 2008. Sikap Terhadap Kekerasan Dalam Berpacaran (Penelitian Pada Mahasiswi Reguler Universitas Esa Unggul Yang Memiliki Pacar.Jurnal Psikologi Vol 6 No 1 Jakarta : Fakultas Psikologi Universitas Esa Unggul Jakarta

Gerungan, W.A. 2002. Psikologi Sosial. Bandung: Refika Aditama

Gunarsa, S. D., \& Gunarsa, Y. S. D. 2004. Psikologi Praktis: Anak, Remaja, dan Keluraga. Jakarta: BPK Gunung Mulia 
Gunarsa, Y. S. D. 2002. Asas-asas Psikologi Keluraga Idaman. Jakarta: BPK Gunung Mulia.

http://akhmadsudrajat.wordpress .com/2008/04/04

http://repository.usu.ac.id/bitstream/1234 56789/31699/3/Chapter\%20II.pdf

http://www.academia.edu/3814377/KEK ERASAN_DALAM_BERPAC ARAN

Hurlock, E. B. 1980. Psikologi Perkembangan. Jakarta: Erlangga

Hurlock, E. B. 1999. Psikologi Perkembangan Anak. Jilid 2. Alih Bahasa : Med. Meitasari Tjandrasa dan Muslichah Zarkasih. Jakarta : Erlangga.

Idrus, Muhammad. 2009. Metode Penelitian Ilmu Sosial. Edisi Kedua. Jakarta: Erlangga.

Indria, K., dan Nindyati, A. D. 2007. Kajian Konformitas dan Kreativitas Affective Remaja. Jurnal Provitae. Vol. 3. No. 1. Hal. 85-108. Jakarta: Fakultas Psikologi Universitas Tarumanagara.

Nazir, Moh. 2003. Metode Penelitian. Jakarta: Ghalia Indonesia.

Rakhmat, J. 2011. Psikologi Komunikasi. Bandung: PT. Remaja Rosdakarya

Santrock,John,W. 2002. Life Span Development : Perkembangan
Sepanjang Hidup, Jilid 1, Jakarta : Erlangga

Sarwono, S. W. 2005. Psikologi Remaja. Jakarta: PT. Raja Grafindo Persada.

Sarwono, Sarlito W. 2010. Psikologi Remaja. Edisi Revisi. Jakarta: Rajawali Pers.

Sears, D.O, Fredman, J. L., dan Peplau, L.A. 2004. Psikologi Sosial : jilid 2. Alih bahasa: Michael Adryanto. Jakarta: Erlangga.

Suharsono, M dan Haryono, A.W. 2009. Sikap Terhadap Demonstrasi Ditinjau Dari Konformitas Pada Kelompok Teman Sebaya. Jurnal Psikodemensia. Volume. 8 No. 1.

Suranto, AW. 2011. Komunikasi Interpersonal. Yogyakarta: Graha Ilmu.

http://bahasa.kompasiana.com/2013/10/2 $0 /$ persepsi-pengertian-definisidan-factor-yangmempengaruhi-600802.html 